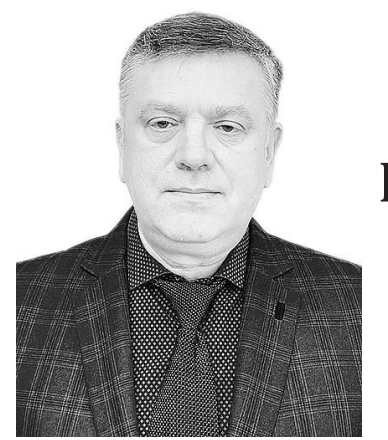

\title{
СТАН НАУКОВИХ ДОСЛІДЖЕНЬ ВІЙСЬКОВИХ ЗЛОЧИНІВ І ДІЯЛЬНОСТІ З ЇХ ВИЯВЛЕННЯ ТА РОЗСЛІДУВАННЯ
}

\author{
БЕРШОВ Геннадій Свгенович - кандидат юридичних наук, \\ голова Другого апеляційного адміністративного суду \\ https://orcid.org/0000-0002-3439-5544 \\ УДК 343.98 \\ DOI 10.32782/LAW.UA.2021.3.10
}

У статті підкреслено, що неможливо
сбормувати рекомендачї стосовно ебек-
тивних засобів виявлення, розслідування
та попередження війсъкових злочинів без ӥх
усебічного дослідження. Наголошено, щз роз-
роблення нових і вдосконалення сучасних-
наукових положень у частині дослідження військових злочинів і діяльності з їх виявлення та розслідування неможливі без урахування вже вироблених $i$ апробованих наукових позицій з окреслених питань. Здійснено аналіз стану наукових розробок з питань визначення поняття, ознак $і$ особливостей кваліббікачї названих протиправних діянь, а також діяльності з їх запобігання, виявлення та розслідування. З’ясовано, що війсъкові злочини є об'єктом дослідження таких наук кримінального изиклу, як кримінальне право, кримінологія, кримінальний процес і криміналістика. Встановлено, що у наукових дослідженнях основна увага приділяється питанням кримінальної відповідальності як групи військових злочинів, так $i$ окремих їх різновидів; призначення війсъковослужбовиям покарання; кримінологічної характеристики вказаних протиправних діянь $i$ їх запобігання. Зазначено, що кримінальні процесуальні та криміналістичні аспекти виявлення та розслідування війсъкових злочинів висвітлено Фрагментарно, що вказує на необхідність більш інтенсивного здійснення наукових пошуків у иъьому напрямі.
Ключові слова: війсъкові злочини, наукові дослідження, криміналістична методика, криміналістична характеристика, досудове розслідування, кримінальне провадження.

\section{Постановка проблеми}

Безпека держави залежить від багатьох факторів, одним із яких $є$ належна організація проходження військової служби. Проте доводиться констатувати, що останніми роками в Україні часто зустрічаються випадки порушення порядку проходження військової служби, зокрема й шляхом вчинення суспільно небезпечних діянь у вказаній сфері. Іншими словами, зростає питома вага скоєних військових злочинів. У цьому контексті особливого значення набуває питання про виявлення, розслідування та попередження військових кримінальних правопорушень. Щоб розробити дієві та прикладні рекомендації стосовно ефективного досудового розслідування військових злочинів, насамперед необхідно з'ясувати стан наукових розробок 3 питань визначення поняття, ознак і особливостей кваліфікації названих протиправних діянь, а також діяльності з їх запобігання, виявлення та розслідування. Саме цим і обумовлюється актуальність обраної тематики дослідження, адже розроблення нових i вдосконалення сучасних наукових положень, зокрема в частині дослідження військових злочинів і діяльності з їх виявлення та розслідування, неможливе без урахуван- 
ня вже вироблених і апробованих наукових позицій з окреслених питань.

\section{Аналіз останніх досліджень і публікацій}

Поняття, сутність, система військових злочинів, а також питання про призначення покарань військовослужбовцям неодноразово досліджували у своїх працях такі вчені, як: Х.М. Ахметшин, 3.О. Ашитов, В.М. Білоконєв, В.П. Бодаєвський, В.О. Бугаєв, В.К. Грищук, М.І. Карпенко, В.І. Касинюк, А.Р. Мухамеджанова, Т.Б. Ніколаєнко, А.М. Ониськів, М.I. Панов, М.М. Сенько, M.C. Туркот, Фалєєв M.I., M.I. Хавронюк та інші. Кримінологічний аналіз військових злочинів здійснювали В.В. Бондарєв, E.M. Пащенко, Е.Б. Пузиревський; специфіку кримінальної процесуальної діяльності в кримінальних провадженнях про окремі військові злочини досліджували М.3. Ауців, О.С. Ткачук; криміналістичну характеристику, рекомендації щодо організації розслідування окремих видів військових злочинів 3 урахуванням ситуаційного підходу та тактики проведення слідчих (розшукових) дій при розслідування вказаних протиправних діянь надавали Ю.М. Береза, В.В. Давиденко, В.С. Давиденко, А.Г. Воєвода, М.I. Карпенко й інші. Проте багато питань досі залишаються малодослідженими чи не дослідженими взагалі. Тому в цій статті ставимо перед собою наступне наукове завдання - за допомогою аналізу наукових напрацювань 3'ясувати стан наукових досліджень військових злочинів і діяльності з їх виявлення та розслідування.

\section{Виклад основного матеріалу дослідження}

Загальноприйнято будь-які кримінальні правопорушення досліджувати науками кримінального циклу 3 різних аспектів, а саме: кримінально-правового, кримінологічного, кримінального процесуального та криміналістичного. У такий спосіб забезпечується всебічність і повнота наукового пошуку, що, у свою чергу, дозволяє виокремити специфіку кримінально-правової кваліфікації кримінальних правопорушень проти встановленого порядку несення вій- ськової служби, визначення детермінант указаних протиправних діянь і заходів з їх запобігання, здійснення кримінальної процесуальної діяльності під час розслідування названих правопорушень і судового провадження стосовно таких суспільно небезпечних діянь, техніко-криміналістичного та тактичного забезпечення діяльності з виявлення та досудового розслідування військових кримінальних правопорушень. Тому, 3'ясовуючи стан наукових досліджень військових злочинів і діяльності з ї виявлення та розслідування, вважаємо за необхідне проаналізувати наукові напрацювання у галузі кримінального права, кримінології, кримінального процесу та криміналістики.

Розслідування кримінальних правопорушень завжди розпочинається з попередньої кримінально-правової кваліфікації протиправного діяння. Відповідно, потрібно чітко розрізняти склади кримінальних правопорушень і кваліфікуючі ознаки суспільно небезпечних діянь. Не є винятком у цьому аспекті й військові злочини, через що велика кількість наукових досліджень присвячена з'ясуванню особливостей визначення складів військових кримінальних правопорушень, їх кримінально-правової кваліфікації, притягненню за їх вчинення до кримінальної відповідальності та призначення покарання.

Передусім слід відзначити, що Україна, формуючи свою правову систему та правову науку, використовує наукові здобутки, отримані науковцями ще за часів Радянського Союзу. Тому вбачається цілком логічним і виправданим той факт, що чимало наукових праць тих часів лягли в основу сучасних наукових досліджень, зокрема присвячених військовим злочинам i їх розслідуванню. У цьому контексті вважаємо доречним назвати основні наукові здобутки радянських учених, які активно використовуються під час формування сучасних наукових позицій і шкіл. Зокрема, M.I. Фалєєв визначає цілі військового покарання [1]; Х.М. Ахметшин визначає особливості кваліфікації військових злочинів [2]; 3.О. Ашитов досліджує кримінальну відповідальність військовослужбовців за порушення порядку користування та збереження воєнного майна [3]; 


\section{Кримінальне право, кримінальний процес та криміналістика}

О.О. Тер-Акопов з'ясовує правові основи відповідальності за військові злочини [4]; А.Г. Горний, Х.М. Ахметшин, О.М. Медвєдєв, Є.М. Самойлов, О.О. Тер-Акопов у коментарях до закону про кримінальну відповідальність за військові злочини надають визначення вказаним злочинам і характеризують склади окремих військових злочинів [5]; 3.М. Абдуллаев досліджує теоретичні основи криміналізації військових суспільно небезпечних діянь [6]; тощо.

За часів незалежності України питання кримінальної відповідальності за військові злочини не втратило своєї актуальності, про що свідчать наступні наукові дослідження.

На дисертаційному рівні питання про кримінальну відповідальність за військові злочини взагалі й окремі їх різновиди досліджувала низка вчених 3 галузі кримінального права. Зокрема, M.I. Хавронюк i М.С. Туркот розглядають питання про кримінальну відповідальність за такий різновид військового злочину як перевищення військовою посадовою особою влади чи посадових повноважень [7; 8]; В.І. Касинюк, B.М. Білоконев визначають особливості кримінальної відповідальності військовослужбовців за порушення правил водіння або експлуатації машин [9]; В.К. Грищук, M.M. Сенько з'ясовують питання кримінальної відповідальності за самовільне залишення військової частини або місця служби [10; 11]; В.П. Бодаєвський встановлює специфіку кримінальної відповідальності військовослужбовців за корисливі посягання на військове майно (ст. 410 КК України) [12]; А.Р. Мухамеджанова здійснює кримінально-правову характеристику насильства над населенням у районі воєнних дій (ст. 433 Кримінального кодексу України) [13]; А.М. Ониськів розглядає питання кримінальної відповідальності за порушення порядку проходження військової служби, вчинені в умовах особливого періоду або в бойовій обстановці [14]; тощо.

Комплексно групу таких кримінальних правопорушень, як військові злочини, а також особливості призначення для вказаних протиправних діянь покарань досліджує В.О. Бугаєв, який у дисертації на тему «Військові злочини і покарання» виявляє специ- фіку кримінально-правових ознак військових злочинів у сучасному українському законодавстві, а також особливості і принципи правового закріплення цих діянь у Кримінальному кодексі України, надає їх характеристику і досліджує відмінність названих злочинів від дисциплінарних проступків i загальнокримінальних діянь; надає юридичну характеристику складу військового злочину, аналізує особливий зміст і специфіку кожного елемента складу; будує та досліджує систему військових злочинів, а також здійснюе аналіз проблеми співучасті в цих діяннях; аналізує особливості кримінальної відповідальності за скоєння військових злочинів і спеціальних покарань, які застосовуються за їх вчинення; розробляє рекомендації щодо правильного застосування норм військово-кримінального законодавства при кваліфікації військових злочинів і призначенні покарань за них; формулюе пропозиції щодо вдосконалення кримінальноправових норм, які регламентують поняття військового злочину та передбачають відповідальність за скоєння конкретних діянь проти порядку несення військової служби, а також відповідних керівних постанов Пленуму Верховного Суду України [15].

Досить детально питання кримінальної відповідальності за злочини проти встановленого порядку несення військової служби, проблеми кваліфікації цих злочинів, відмежування їх від суміжних злочинів та діянь, що не $є$ злочинними, розглядаються авторським колективом за ред. M.I. Панова у навчальному посібнику «Злочини проти встановленого порядку несення військової служби (військові злочини)» [16].

Не меншу увагу проблематиці визначення поняття, системи та кваліфікації військових злочинів за кримінальним правом України приділяє й С.О. Харитонов. Учений у своїх наукових працях розглядає теоретичні й методологічні засади кримінальної відповідальності за військові злочини, проводить історико-порівняльний дискурс та визначає соціальну обумовленість кримінальної відповідальності за ці злочини; здійснює теоретичне узагальнення і пропонує нове вирішення питань про поняття «військовий злочин» та «склад військового 
злочину»; визначає систему військових злочинів та іï місце в системі Кримінального кодексу України; розглядає спірні питання кваліфікації військових злочинів та особливості застосування покарання [17; 18].

Теоретичні та прикладні аспекти злочинів проти встановленого порядку несення військової служби (військових злочинів) досліджує М.І. Карпенко. При цьому науковцем здійснено аналіз витоків та генези кримінальної відповідальності за військові злочини на теренах сучасної України за період з XI ст. по сьогодення; розглянуто питання історії становлення системи військових злочинів, військового правопорядку як об'єкта кримінально-правової охорони, об'єктносуб'єктну характеристику військових злочинів, питання кваліфікації та заходи кримінально-правового характеру за їх вчинення; здійснено порівняльно-правовий аналіз системи військових злочинів за КК України та інших держав світу; сформульовано пропозиції щодо перегляду як змісту родового об'єкта військових злочинів, так і системи в цілому [19; 20].

Теоретико-правові засади призначення та виконання спеціальних покарань щодо військовослужбовців визначає Т.Б. Ніколаєнко. Зокрема, вчена розкриває особливості генези становлення інституту спеціальних покарань, що призначаються військовослужбовцям, у їхній історичній ретроспективі; розробляє методологічну основу дослідження та доводить, що покарання, застосовувані до військовослужбовців, становлять невід'ємний елемент єдиної системи покарань; досліджує правовий статус військовослужбовця як суб’єкта кримінально-правових правовідносин, характеризує його сутність та ознаки; виявляє тенденції застосування спеціальних покарань до військовослужбовців, зважаючи на зміни правового режиму в державі й з огляду на гуманізацію законодавства, перспективи їхнього розвитку [21].

Поряд із кримінально-правовою характеристикою військових злочинів чимало вчених здійснює кримінологічну характеристику виокремлених протиправних діянь 3 метою визначення їх детермінант і ефективних заходів їх запобігання. Інши- ми словами, військові злочини виступають об'єктом дослідження багатьох учених-кримінологів. Наприклад, В.В. Бондарєв здійснює кримінологічний аналіз нестатутних взаємовідносини серед військовослужбовців Збройних сил України, а також насильства серед військовослужбовців і пропонує способи їх попередження [22; 23]; Є.Б. Пузиревський піддає кримінологічному аналізу групу військових злочинів, у результаті чого виокремлює причини й умови вчинення названих діянь і визначає особливості їх запобігання [24]; Є.М. Пащенко надає кримінологічну характеристику та вказує на шляхи та засоби запобігання насильницькій злочинності військовослужбовців [25]; і т. п.

Кримінально-правова кваліфікація військових злочинів здійснюється задля визначення складу конкретного протиправного діяння, щоб забезпечити ефективне його досудове розслідування та судове провадження. Тільки в такому разі вдасться притягнути винних осіб і призначити їм заслужене покарання. У зв'язку з цим важливо досліджувати не тільки кримінальні правопорушення проти встановленого порядку несення військової служби, а й діяльність з їх виявлення та розслідування. Цим займаються вчені-фахівці в галузі кримінального процесу та криміналістики. Разом із тим варто відзначити, що питанню виявлення та розслідування військових злочинів приділялося значно менше уваги, аніж їх кримінально-правовій і кримінологічній характеристиці. Зокрема, специфіку кримінальної процесуальної діяльності у кримінальних провадженнях про злочини проти встановленого порядку несення військової служби (статті 407-409 Кримінального кодексу України) на стадії досудового розслідування з'ясовує М.З. Ауців [26], а особливості судового слідства як складової судового провадження у справах про насильство серед військовослужбовців встановлює О.С. Ткачук [27].

Криміналістичні рекомендації стосовно методики розслідування окремих різновидів військових злочинів, а також тактики та техніко-криміналістичного забезпечення проведення окремих слідчих (розшукових) дій можна зустріти в працях наступних науковців. В.С. Давиденко у кандидатській дис- 


\section{Кримінальне право, кримінальний процес та криміналістика}

ертації формує основи методики розслідування злочинів, пов'язаних 3 порушенням статутних правил взаємовідносин між військовослужбовцями за відсутності відносин підлеглості [28], а в монографічному дослідженні визначає й характеризує проблеми тактики та методики розслідування насильницьких злочинів, вчинених військовослужбовцями [29]; А.Г. Воєвода наводить основні положення методики розслідування злочинів, пов'язаних з порушенням правил водіння або експлуатації військових машин [30]; В.В. Давиденко будує методику розслідування самовільного залишення військової частини або місця служби [31]; Ю.М. Береза, К.О. Чаплинський визначають теоретичні засади методики розслідування незаконного заволодіння військовослужбовцем зброєю, бойовими припасами та вибуховими речовинами [32]; і т. д.

М.I. Карпенко у монографії за редакцією В.К. Матвійчука здійснює комплексне дослідження військових злочинів 3 декількох аспектів. Мова йде про те, що вчений поряд із кримінально-правовою характеристикою злочинів, передбачених розділом XIX Особливої частини Кримінального кодексу України, до системи яких, окрім загальновійськових та службових злочинів, відносяться спеціальні військові злочини, пов’язані 3 відповідальністю за жорстоке, нелюдське поводження або насильство над населенням та дотриманням їх фундаментальних прав з боку військових службових осіб, визначає особливості методики розслідування окремих різновидів військових злочинів, а також визначає причини вчинення та заходи із запобігання як військових злочинів узагалі, так і насильницьких злочинів військовослужбовців, корисливих злочинів військовослужбовців, військових злочинів анархічної мотивації, необережних злочинів легковажної мотивації зокрема [33].

\section{Висновки}

Отже, військові злочини є об'єктом дослідження наук кримінального циклу, через що стан їх наукових досліджень та діяльності з їх виявлення та розслідування з'ясовано за допомогою аналізу наукових напрацювань 3 таких галузей знань як кримінальне право, кримінологія, кримінальний процес і криміналістика. Наголошено, що у наукових дослідженнях основна увага приділяеться питанням кримінальної відповідальності як групи військових злочинів, так і окремих їх різновидів; призначення військовослужбовцям покарання; кримінологічної характеристики вказаних протиправних діянь i ïx запобігання. При цьому кримінальні процесуальні та криміналістичні аспекти виявлення та розслідування військових злочинів висвітлено фрагментарно, що вказує на необхідність більш інтенсивного здійснення наукових пошуків у цьому напрямі.

\section{Аітература}

1. Фалеев Н.И. Цели воинского наказания: дис. ... экстраординар. проф. на каф. воен.-угол. законов в Александр. воен.-юрид. акад. Санкт-Петербург: Тип. В.С. Балашевъ и Ко, 1902. 525 с.

2. Ахметшин Х. М. Квалификация воинских преступлений: учеб. пособие. Москва: Воен. ин-т, 1977. 80 с.

3. Ашитов 3.О. Уголовная ответственность военнослужащих за нарушение порядка пользования и сбережения военного имущества: автореф. дис. ... канд. юрид. наук: спец. 12.00.08. Алма-Ата, 1960. 24 с.

4. Тер-Акопов А.А. Правовые основания ответственности за воинские преступления: дис. ... д-ра юрид. наук: 20.02.03. Москва, 1982. 362 c.

5. Закон об уголовной ответственности за воинские преступления. Комментарии / Ахметшин Х.М., Медведев А.М., Самойлов Е.М., Тер-Акопов А.А.; под ред.: Горный А.Г. М.: Юрид. лит., 1986. 160 с.

6. Абдуллаев 3.М. Теоретические основы криминализации воинских общественно опасных деяний: дис. ... канд. юрид. наук: 20.02.03. Москва, 1991. 208 с.

7. Хавронюк М.I. Кримінальна відповідальність за перевищення військовою посадовою особою влади чи посадових повноважень: автореф. дис. ... канд. юрид. наук: спец. 12.00.08. Київ, 1998. 25 с.

8. Туркот М.С. Кримінальна відповідальність за зловживання військовою службовою особою владою або службовим стано- 
вищем: автореф. дис. ... канд. юрид. наук: спец. 12.00.08. Харків, 2007. 20 с.

9. Касинюк В.І., Білоконев В.М. Кримінальна відповідальність військовослужбовців за порушення правил водіння або експлуатації машин. Запоріжжя: Глазунов C.O., 2001. 231 с.

10. Сенько М.М. Кримінальна відповідальність за самовільне залишення військової частини або місця служби: автореф. дис. ... канд. юрид. наук: спец. 12.00.08. Київ, 2005. 18 с.

11. Грищук В.К., Сенько М.М. Кримінальна відповідальність за самовільне залишення військової частини або місця служби: монографія. Аьвів: Аьвів. держ. ун-т внутр. справ, 2007. 308 с.

12. Бодаєвський В.П. Кримінальна відповідальність військовослужбовців за корисливі посягання на військове майно (ст. 410 КК України): автореф. дис. ... канд. юрид. наук: спец. 12.00.08. Запоріжжя, 2010. 16 с.

13. Мухамеджанова A.P. Кримінальноправова характеристика насильства над населенням у районі воєнних дій (ст. 433 Кримінального кодексу України): автореф. дис. ... канд. юрид. наук: спец. 12.00.08. Харків, 2017. 16 c.

14. Ониськів А.М. Кримінальна відповідальність за порушення порядку проходження військової служби, вчинені в умовах особливого періоду або в бойовій обстановці: автореф. дис. ... канд. юрид. наук: спец. 12.00.08. Київ, 2017. 20 с.

15. Бугаєв В.О. Військові злочини та покарання: автореф. дис. ... канд. юрид. наук: спец. 12.00.08. Одеса, 2002. 21 с.

16. Злочини проти встановленого порядку несення військової служби (військові злочини): навч. посіб. / Г.М. Анісімов та ін.; за ред. М.І. Панова. Х.: Право, 2011. 184 с.

17. Харитонов С.О. Кримінальна відповідальність за військові злочини за кримінальним правом України: монографія. Харків: Право, 2018. 328 с.

18. Харитонов С.О. Військові злочини: поняття, система та проблеми кваліфікації: автореф. дис. ... докт. юрид. наук: спец. 12.00.08. Харків, 2019. 43 с.

19. Карпенко M.I. Злочини проти встановленого порядку несення військової служби (військові злочини): теоретичні та прикладні аспекти: монографія. Київ: Нац. акад. упр., 2018. 420 с.

20. Карпенко М.I. Військові злочини: питання теорії, законодавства і практики: монографія / за заг. ред. В.К. Матвійчука. Київ: ЗВО «Національна академія управління», 2019. 458 с.

21. Ніколаєнко Т.Б. Теоретико-правові засади призначення та виконання спеціальних покарань щодо військовослужбовців: дис. ... докт. юрид. наук: 12.00.08. Київ, 2019. 556 c.

22. Бондарєв В.В. Нестатутні взаємовідносини серед військовослужбовців Збройних сил України: кримінологічний аналіз та попередження: автореф. дис. ... канд. юрид. наук: спец. 12.00.08. Київ, 2001. 19 c.

23. Бондарєв В.В. Насильство серед військовослужбовців (поняття, характеристика, причини та попередження). Київ: Київ. нац. торг.-екон. ун-т, 2002. 272 с.

24. Пузиревський С.Б. Кримінологічний аналіз і запобігання військовим злочинам: автореф. дис. ... канд. юрид. наук: спец. 12.00.08. Харків, 2011. 22 с.

25. Пащенко E.M. Кримінологічна характеристика та запобігання насильницькій злочинності військовослужбовців: дис. ... докт. філософії: спец. 081 - Право. Харків, 2021. 225 c.

26. Ауців М.3. Особливості досудового розслідування злочинів проти встановленого порядку несення військової служби (статті 407-409 Кримінального кодексу України): автореф. дис. ... канд. юрид. наук: спец. 12.00.09. Харків, 2020. 20 с.

27. Ткачук О.С. Судове слідство у кримінальних справах про насильство серед військовослужбовців. Київ: КНТ, 2007. 172 с.

28. Давиденко В.С. Основи методики розслідування злочинів, пов'язаних з порушенням статутних правил взаємовідносин між військовослужбовцями за відсутності відносин підлеглості: дис. ... канд. юрид. наук: спец. 12.00.09. Київ, 2006. 313 с.

29. Давиденко В.С. Розслідування насильницьких злочинів, вчинених військовослужбовцями: проблеми тактики та методики: монографія. К.: Атіка, 2010. 272 с. 


\section{Кримінальне право, кримінальний процес та криміналістика}

30. Воєвода А.Г. Основні положення методики розслідування злочинів, пов'язаних 3 порушенням правил водіння або експлуатації військових машин: дис. ... канд. юрид. наук: спец. 12.00.09. Київ, 2014. 253 с.

31. Давиденко В.В. Методика розслідування самовільного залишення військової частини або місця служби: дис... канд. юрид. наук: спец. 12.00.09. Київ, 2015. 322 с.

32. Береза Ю.М., Чаплинський К.О. Теоретичні засади методики розслідування незаконного заволодіння військовослужбовцем зброєю, бойовими припасами та вибуховими речовинами: монографія. Київ: Видавничий дім «Гельветика», 2018. 155 с.

33. Карпенко M.I. Військові злочини: характеристика, методика розслідування та запобігання: посібник / за заг. ред. д. ю. н., проф. В.К. Матвійчука. К.: ВД «Дакор», 2013. 472 c.

Bershov Hennadii Yevhenovych, president judge of the Second Administrative Court of Appeals, PhD (Candidate of Jurisprudence)

THE STATE OF SCIENTIFIC RESEARCH OF MILITARY CRIMES AND ACTIVITIES FOR THEIR DETECTION AND INVESTIGATION

In the article has been emphasized that it is not possible to formulate recommendations on effective means of detecting, investigating and preventing war crimes without comprehensive investigation. It has been emphasized that the development of new and improvement of existing scientific provisions in terms of research of war crimes and activities for their detection and investigation is impossible without taking into account the already developed and tested scientific positions on the outlined issues. The analysis of a condition of scientific developments in the field of definition of concept, signs and features of qualification of the named illegal actions, and also activity on their prevention, detection and investigation has been carried out. It has been established that war crimes are the object of study of such sciences of the criminal cycle as criminal law, criminology, criminal procedure and criminology. The study of war crimes in several respects ensures the comprehensiveness and completeness of scientific research, which, in turn, allows to identify the specifics of criminal qualification of criminal offenses against the established order of military service, determining the determinants of these illegal acts and measures to prevent them, criminal proceedings during the investigation of the mentioned offenses and court proceedings concerning such socially dangerous acts, technical-criminological and tactical support of activity on detection and pre-trial investigation of military criminal offenses. It has been established that in scientific researches the main attention is paid to questions of criminal responsibility both of group of war crimes, and their separate kinds; sentencing servicemen; criminological characteristics of these illegal acts and their prevention. Criminal law qualification of war crimes is carried out in order to determine the composition of a particular illegal act, to ensure its effective pre-trial investigation and trial. Only in this case will it be possible to attract the guilty and impose a deserved punishment. In this regard, it is important to investigate not only criminal offenses against the established order of military service, but also activities to identify and investigate them. It has been noted that the criminal procedural and forensic aspects of detection and investigation of war crimes are covered in fragments, which indicates the need for more intensive research in this area.

Keywords: war crimes, scientific research, forensic methods, forensic characteristics, pretrial investigation, criminal proceedings. 